\title{
Analisis Perbandingan Model Gates, Ackoff \& Sasieni, dan Friedman dalam Simulasi Strategi Penawaran Tender Proyek Peningkatan Jalan di Kota Bandung
}

\author{
Felix Hidayat ${ }^{1 *}$, Huzein Muhammad Ramdhan ${ }^{1}$, Muchammad Sarwono Purwa Jayadi ${ }^{1}$ \\ Dikirim: 16/08/2021 \\ Diterima: 15/09/2021
}

\begin{abstract}
ABSTRAK
Menentukan harga penawaran yang penting bagi kontraktor dalam mengikuti tender proyek konstruksi. Oleh karena itu, penelitian ini melakukan penelitian mengenai beberapa model strategi penawaran untuk mendapatkan mark up beserta probabilitas menang. Diantaranya dipilih model Gates, Ackoff \& Sasieni, dan Friedman. Penelitian ini menggunakan metode purposive sampling dengan sampel data proyek peningkatan jalan yang diambil dari laman LPSE kota Bandung tahun 2015-2017 sejumlah 116 data. 86 data digunakan untuk analisis model Gates, Ackoff \& Sasieni, dan Friedman, kemudian 30 data disisihkan untuk uji validitas. Dari penelitian ini didapatkan grafik mark up vs. Probabilitas menang dari masing-masing model yang dapat digunakan oleh kontraktor sebagai acuan dalam menetapkan harga penawaran. Model Gates menghasilkan nilai mark up optimum untuk distribusi normal berganda, normal tunggal, dan diskrit berganda secara berurutan sebesar $6 \%, 7 \%$, dan $6 \%$. Model Ackoff \& Sasieni menghasilkan nilai mark up optimum untuk distribusi normal berganda, normal tunggal, dan diskrit berganda secara berurutan sebesar $6 \%, 6 \%$, dan $6 \%$. Model Friedman menghasilkan nilai mark up optimum untuk distribusi normal berganda, normal tunggal, dan diskrit berganda secara berurutan sebesar 3\%, 3\%, dan 2\%. Dari hasil tersebut dapat disimpulkan bahwa model Friedman menghasilkan harga penawaran terendah, namun pesimis dalam memberikan nilai mark up berdasarkan uji validitas.
\end{abstract}

Kata kunci: mark up, probabilitas menang, model Gates, model Ackoff \& Sasieni, model Friedman.

\section{PENDAHULUAN}

Proyek konstruksi adalah sebuah kegiatan yang bersifat sementara yang telah ditetapkan awal pekerjaannya dan waktu selesainya untuk mencapai tujuan dan hasil yang spesifik dan unik [1]. Pada sebuah proyek konstruksi, umumnya terdapat lima tahapan utama, yaitu inisiasi (initiation), perencanaan (planning), pelaksanaan (executing), pemantauan dan pengendalian (monitoring \& controlling), dan penutupan (closing) [2]. Pada proses perencanaan, suatu proyek direncanakan sedemikian rupa sehingga proyek yang akan dilakukan tepat biaya, tepat waktu, dan tepat mutu.

Setelah tahap perencanaan pada sebuah proyek selesai maka akan dilanjutkan dengan tahap pengadaan pelaksanaan (procurement) yaitu tahapan pemilihan penyelenggara proyek oleh pemilik (owner), yaitu kontrakor agar proyek dapat dilaksanakan. Di Indonesia proses pengadaan merujuk pada Peraturan Pemerintah Republik Indonesia Nomor 29 Tahun 2000 tentang Penyelenggaraan Jasa Konstruksi [3] yaitu dengan pemilihan langsung, penunjukan langsung, pelelangan (umum maupun terbatas). Dari semua metode pengadaan diatas, pelelangan dianggap paling sederhana dan adil bagi seluruh peserta [4] oleh karena itu lelang sering digunakan. Selain itu, pelelangan di Indonesia juga sudah mulai menggunakan metode daring dan

\footnotetext{
${ }^{1}$ Universitas Katolik Parahyangan, Jl. Ciumbuleuit No.94, Bandung 40141

* hidayat@unpar.ac.id
} 
diatur dalam Peraturan Presiden Republik Indonesia Nomor 54 Tahun 2010 tentang Pengadaan Barang/Jasa Pemerintah [5].

Sebelum proses pelelangan dibuka, pemilik proyek terlebih dahulu menetapkan Harga Perkiraan Sendiri (HPS). Menurut Peraturan Presiden Nomor 16 Tahun 2018 [6], Harga Perkiraan Sendiri adalah perkiraan harga barang/jasa yang ditetapkan oleh Pejabat Pembuat Komitmen (PPK). HPS umumnya digunakan sebagai batas tertinggi penawaran yang sah untuk pengadaan. Pada umumnya pelelangan dilakukan dengan metode low-bid, yaitu proses pelelangan yang memilih penawar terendah sebagai pemenang.

Ada dua masalah utama bagi kontraktor saat menetapkan harga penawaran. Pertama apabila kontraktor mengajukan harga yang terlalu tinggi dengan harapan mendapatkan keuntungan yang besar, probabilitas untuk memenangkan tender menjadi menurun. Namun apabila kontraktor mengajukan harga yang rendah dengan harapan meningkatkan probabilitas untuk memenangkan tender, kontraktor akan menerima keuntungan yang rendah atau mengurangi kualitas barang dan/atau jasa yang ditawarkan [7]. Setiap masalah yang dihadapi oleh kontrakor membutuhkan solusi yang berbeda, tergantung dari tujuannya. Namun tujuan utama yang paling umum adalah untuk memaksimalkan total keuntungan [8].

Banyak model matematis yang tersedia untuk membantu kontraktor untuk membuat penawaran tender yang optimum, diantaranya yaitu Model Gates, Ackoff \& Sasieni, dan Friedman [8]. Dengan ketiga model tersebut dapat diketahui mark up atau peningkatan harga yang optimum berdasarkan perhitungan data terdahulu. Kontraktor kemudian dapat memberikan penawaran harga berdasarkan seberapa besar keuntungan yang diinginkan. Ketiga model diatas digunakan dengan asumsi kontraktor memiliki tujuan utama untuk memaksimalkan total keuntungan. Ketiga model diatas sama-sama menggunakan pendekatan probabilitas, namun rumus pendekatan probabilitasnya berbeda.

Pada penelitian ini akan dilakukan perbandingan model strategi penawaran Gates, Ackoff \& Sasieni dan Friedman untuk meneliti besaran nilai mark up optimum dari masing-masing model tersebut. Dari ketiga variasi nilai mark up optimum tersebut kemudian akan diuji dengan data pelelangan yang pernah dilakukan. Penelitian ini akan mengaplikasikan tiga model tersebut pada simulasi proyek peningkatan jalan di kota Bandung karena sebelumnya belum pernah ada penelitian yang membandingkan ketiga model tersebut di kota Bandung.

Tujuan dari penelitian ini adalah sebagai berikut:

1) Memberikan gambaran matematis dari model strategi penawaran Gates, Ackoff \& Sasieni, dan Friedman yang berupa grafik mark up vs. probabilitas menang.

2) Menghitung nilai mark up optimum dari penawaran tender proyek konstruksi di kota Bandung menggunakan pendekatan model strategi penawaran Gates, Ackoff \& Sasieni, dan Friedman.

3) Membandingkan model strategi penawaran Gates, Ackoff \& Sasieni, dan Friedman berdasarkan nilai mark up optimum dan probabilitas menang.

4) Menguji aplikasi model strategi penawaran Gates, Ackoff \& Sasieni, dan Friedman dalam menentukan nilai mark up pada tender proyek peningkatan jalan di kota Bandung.

\section{TINJAUAN PUSTAKA Harga Perkiraan Sendiri (HPS)}

Menurut Peraturan Presiden Nomor 16 Tahun 2018, Harga Perkiraan Sendiri (HPS) adalah perkiraan harga barang/jasa yang ditetapkan oleh Pejabat Pembuat Komitmen (PPK). Sesuai dengan Peraturan Presiden Nomor 16 Tahun 2018 [6], HPS dihitung dengan memperhitungkan keuntungan pelaksana dan biaya tak langsung (overhead cost). Pada Konsolidasi Nomor 54 Tahun 2010 [5], juga disebutkan bahwa keuntungan yang diperoleh oleh kontraktor yang secara wajar digunakan dalam penentuan HPS maksimal sebesar 15\%. Berdasarkan peraturan tersebut, berarti HPS pada pengadaan barang/jasa pemerintah umumnya bernilai lebih tinggi hingga $15 \%$ dari biaya aktual. Secara tidak langsung berarti apabila peserta tender menang dan HPS 
digunakan sebagai biaya aktual proyek, maka peserta tender sudah mendapatkan keuntungan hingga $15 \%$.

\section{Mark Up}

Mark Up didefinisikan sebagai selisih harga penawaran dan biaya estimasi dibagi dengan biaya estimasi.

$$
\operatorname{MarkUp}=\frac{b-c}{c}
$$

dengan $\mathrm{b}=$ harga penawaran (bid), $\mathrm{c}=$ biaya estimasi (cost)

\section{Expected Profit}

Untuk mendapatkan potential profit yang optimum, perlu dicari nilai expected profit yang optimum. Expected profit didefinisikan sebagai probabilitas menang dikali dengan mark up.

$$
E(P)=P \cdot \operatorname{Mark} U p
$$

dengan $\mathrm{E}(\mathrm{P})=$ expected profit, $\mathrm{P}=$ probabilitas menang

\section{Model Gates}

Model Gates menggunakan perumusan probabilitas menang untuk identitas pesaing dikenal sebagai berikut [9]:

$$
P\left(C_{0} \text { Win } / B_{0}\right)=\frac{1}{1+\sum_{i=0}^{n} \frac{1-P\left(B_{0}<B_{i}\right)}{P\left(B_{0}<B_{i}\right)}}
$$

dengan $\mathrm{P}\left(\mathrm{C}_{0}\right.$ Win $\left./ \mathrm{B}_{0}\right)=$ probabilitas menang semua pesaing, $\mathrm{P}\left(\mathrm{B}_{0} / \mathrm{B}_{\mathrm{i}}\right)=$ probabilitas menang terhadap pesaing $\mathrm{i}, \mathrm{n}=$ jumlah pesaing

\section{Model Ackoff \& Sasieni}

Perumusan probabilitas menang Ackoff \& Sasieni hanya dihitung terhadap pesaing terendah saja [9], sebagai berikut:

$$
P\left(C_{0} \operatorname{Win} / B_{0}\right)=P\left(B_{0}<B_{i}\right)
$$

dengan $P\left(C_{0}\right.$ Win $\left./ B_{0}\right)=$ probabilitas menang semua pesaing, $P\left(B_{0} / B_{i}\right)=$ probabilitas menang terhadap pesaing terendah

\section{Model Friedman}

Model Friedman merupakan model sederhana berbasis teori probabilitas (Friedman, 1956)[8]. Model Friedman menggunakan perumusan probabilitas menang untuk identitas pesaing dikenal sebagai berikut:

$$
P\left(C_{0} \text { Win } / B_{0}\right)=P\left(B_{0}<B_{1}\right) \cdot\left(B_{0}<B_{i}\right) \cdot \ldots \cdot\left(B_{0}<B_{n}\right)
$$

dengan dengan $P\left(C_{0}\right.$ Win $\left./ B_{0}\right)=$ probabilitas menang semua pesaing, $P\left(B_{0} / B_{i}\right)=$ probabilitas menang terhadap pesaing $\mathrm{i}$.

\section{METODOLOGI PENELITIAN}

Metodologi penelitian yang digunakan dalam penelitian isi adalah sebagai berikut:

1) Studi Literatur

Studi literatur dilakukan dengan mengumpulkan literatur yang berasal dari buku, paper, artikel, dan jurnal penelitian yang digunakan sebagai landasan teori penelitian. Ruang lingkup dalam penelitian ini mencakup konsep dasar proyek konstruksi, sistem tender, dan Model Gates, Ackoff \& Sasieni, dan Friedman. 
2) Pengumpulan Data Sekunder

Pengumpulan data sekunder dilakukan dengan pengambilan data dari laman Layanan Pengadaan Secara Elektronik (LPSE) kota Bandung untuk mendapatkan data yang digunakan dalam analisis. Data tender merupakan data tender proyek dengan kata kunci "peningkatan jl." Dari tahun 2015 sampai 2017 sejumlah 118 data. Dari 118 data tersebut digunakan

3) Analisis Data

Analisis data dilakukan dengan mengolah data sekunder menggunakan model strategi penawaran Gates, Ackoff \& Sasieni, dan Friedman dengan pendekatan statistik diskrit berganda, normal tunggal, dan normal berganda untuk mendapatkan nilai probabilitas menang dari masing-masing model, kemudian dilanjutkan dengan perhitungan expected profit optimum untuk mencari nilai mark up optimum dari masing-masing model.

4) Analisis Perbandingan Model

Analisis perbandingan model dilakukan dengan membandingkan nilai mark up optimum dan probabilitas menang dari model strategi penawaran Gates, Ackoff \& Sasieni, dan Friedman untuk mengetahui model yang menghasilkan mark up optimum terendah.

5) Uji Validitas

Probabilitas menang dari mark up optimum semua model kemudian dibandingkan dengan persentase menang dari 30 data yang telah disisihkan, kemudian dihitung selisihnya untuk mengetahui tingkat akurasi dari model-model yang diuji.

6) Kesimpulan

Penarikan kesimpulan berdasarkan analisis data dilakukan untuk menjawab tujuan penelitian.

\section{HASIL DAN PEMBAHASAN}

\section{Pengolahan Data}

Data sekunder berupa harga penawaran diubah menjadi rasio penawaran terhadap biaya estimasi kemudian didistribusi menggunakan metode distribusi normal berganda, normal tunggal, dan diskrit berganda.

Tabel 1. Mean, Standar Deviasi dan Varian dengan Distribusi Normal Berganda

\begin{tabular}{cccccccc}
\hline \multirow{2}{*}{ Hasil Statistik } & \multicolumn{7}{c}{ Kontraktor } \\
\cline { 2 - 8 } & A & B & C & D & E & F & G \\
\hline Mean & 0,948 & 0,971 & 0,985 & 0,989 & 0,993 & 0,990 & 0,984 \\
Standar Deviasi & 0,095 & 0,094 & 0,095 & 0,096 & 0,098 & 0,095 & 0,090 \\
Varian & 0,0090 & 0,0088 & 0,0091 & 0,0092 & 0,0097 & 0,0090 & 0,0081 \\
\hline
\end{tabular}

Tabel 2. Mean, Standar Deviasi dan Varian dengan Distribusi Normal Tunggal

\begin{tabular}{ccc}
\hline Hasil Statistik & $\mathbf{2 0 1 5 - 2 0 1 7}$ & \\
\hline \multirow{2}{*}{ Bid/Cost } & Mean & 0,977 \\
& Standar Deviasi & 0,096 \\
& Varian & 0,0091 \\
\multirow{2}{*}{ Low Bid/Cost } & Mean & 0,948 \\
& Standar Deviasi & 0,095 \\
& Varian & 0,0090 \\
\hline
\end{tabular}

Dilanjutkan dengan perhitungan probabilitas menang dari masing-masing model distribusi. 
Tabel 3. Probabilitas Menang untuk Distribusi Normal Berganda

\begin{tabular}{ccccccccc}
\hline Mark Up (\%) & $\mathbf{R}$ & $\mathbf{p A}$ & $\mathbf{p B}$ & $\mathbf{p C}$ & $\mathbf{p D}$ & $\mathbf{p E}$ & $\mathbf{p F}$ & $\mathbf{p G}$ \\
\hline-35 & 0,65 & 0,999 & 1,000 & 1,000 & 1,000 & 1,000 & 1,000 & 1,000 \\
-30 & 0,70 & 0,995 & 0,998 & 0,999 & 0,999 & 0,999 & 0,999 & 0,999 \\
-25 & 0,75 & 0,981 & 0,991 & 0,993 & 0,993 & 0,993 & 0,994 & 0,995 \\
-20 & 0,80 & 0,940 & 0,966 & 0,974 & 0,975 & 0,975 & 0,978 & 0,980 \\
-15 & 0,85 & 0,849 & 0,902 & 0,921 & 0,925 & 0,927 & 0,931 & 0,932 \\
-10 & 0,90 & 0,693 & 0,776 & 0,813 & 0,822 & 0,828 & 0,829 & 0,825 \\
-5 & 0,95 & 0,492 & 0,589 & 0,642 & 0,656 & 0,670 & 0,664 & 0,648 \\
0 & 1,00 & 0,292 & 0,378 & 0,436 & 0,453 & 0,472 & 0,459 & 0,431 \\
5 & 1,05 & 0,142 & 0,199 & 0,246 & 0,262 & 0,281 & 0,264 & 0,233 \\
10 & 1,10 & 0,055 & 0,084 & 0,113 & 0,123 & 0,139 & 0,123 & 0,099 \\
15 & 1,15 & 0,017 & 0,028 & 0,041 & 0,047 & 0,005 & 0,046 & 0,033 \\
20 & 1,20 & 0,004 & 0,007 & 0,012 & 0,014 & 0,018 & 0,013 & 0,008 \\
\hline
\end{tabular}

Tabel 4. Probabilitas Menang untuk Distribusi Normal Tunggal

\begin{tabular}{ccccccccccccc}
\hline Mark Up (\%) & -35 & -30 & -25 & -20 & -15 & -10 & -5 & 0 & 5 & 10 & 15 & 20 \\
$\mathbf{R}$ & 0,65 & 0,70 & 0,75 & 0,80 & 0,85 & 0,90 & 0,95 & 1,00 & 1,05 & 1,10 & 1,15 & 1,20 \\
Probabilitas & 1,000 & 0,998 & 0,991 & 0,968 & 0,909 & 0,791 & 0,613 & 0,407 & 0,224 & 0,100 & 0,305 & 0,010 \\
\hline
\end{tabular}

Tabel 5. Probabilitas Menang untuk Distribusi Diskrit Berganda

\begin{tabular}{ccccccccc}
\hline \multirow{2}{*}{ Mark Up (\%) } & \multicolumn{7}{c}{ Probabilitas Menang Kontraktor } \\
\cline { 2 - 8 } & $\mathbf{R}$ & $\mathbf{A}$ & $\mathbf{B}$ & $\mathbf{C}$ & $\mathbf{D}$ & $\mathbf{E}$ & $\mathbf{F}$ & $\mathbf{G}$ \\
\hline-30 & 0,70 & 1,000 & 1,000 & 1,000 & 1,000 & 1,000 & 1,000 & 1,000 \\
-25 & 0,75 & 0,988 & 1,000 & 1,000 & 1,000 & 1,000 & 1,000 & 1,000 \\
-20 & 0,80 & 0,942 & 0,988 & 1,000 & 1,000 & 1,000 & 1,000 & 1,000 \\
-15 & 0,85 & 0,860 & 0,940 & 0,933 & 0,922 & 0,929 & 0,918 & 0,976 \\
-10 & 0,90 & 0,756 & 0,759 & 0,800 & 0,844 & 0,857 & 0,837 & 0,857 \\
-5 & 0,95 & 0,547 & 0,602 & 0,600 & 0,609 & 0,625 & 0,612 & 0,619 \\
0 & 1,00 & 0,360 & 0,446 & 0,533 & 0,547 & 0,518 & 0,469 & 0,500 \\
5 & 1,05 & 0,174 & 0,253 & 0,333 & 0,359 & 0,375 & 0,388 & 0,357 \\
10 & 1,10 & 0,070 & 0,120 & 0,173 & 0,203 & 0,214 & 0,204 & 0,167 \\
15 & 1,15 & 0,000 & 0,012 & 0,000 & 0,000 & 0,036 & 0,000 & 0,000 \\
\hline
\end{tabular}

Grafik Mark Up vs. Probabilitas Menang Model Gates, Ackoff \& Sasieni, dan Friedman Hasil Perhitungan probabilitas menang dari masing-masing metode distribusi digunakan untuk menghitung probabilitas menang terhadap semua pesaing dikenal menggunakan model strategi penawaran Gates, Ackoff \& Sasieni, dan Friedman. Kemudian probabilitas menang dan mark up digunakan untuk membuat grafik hubungan probabilitas menang vs. mark up. 


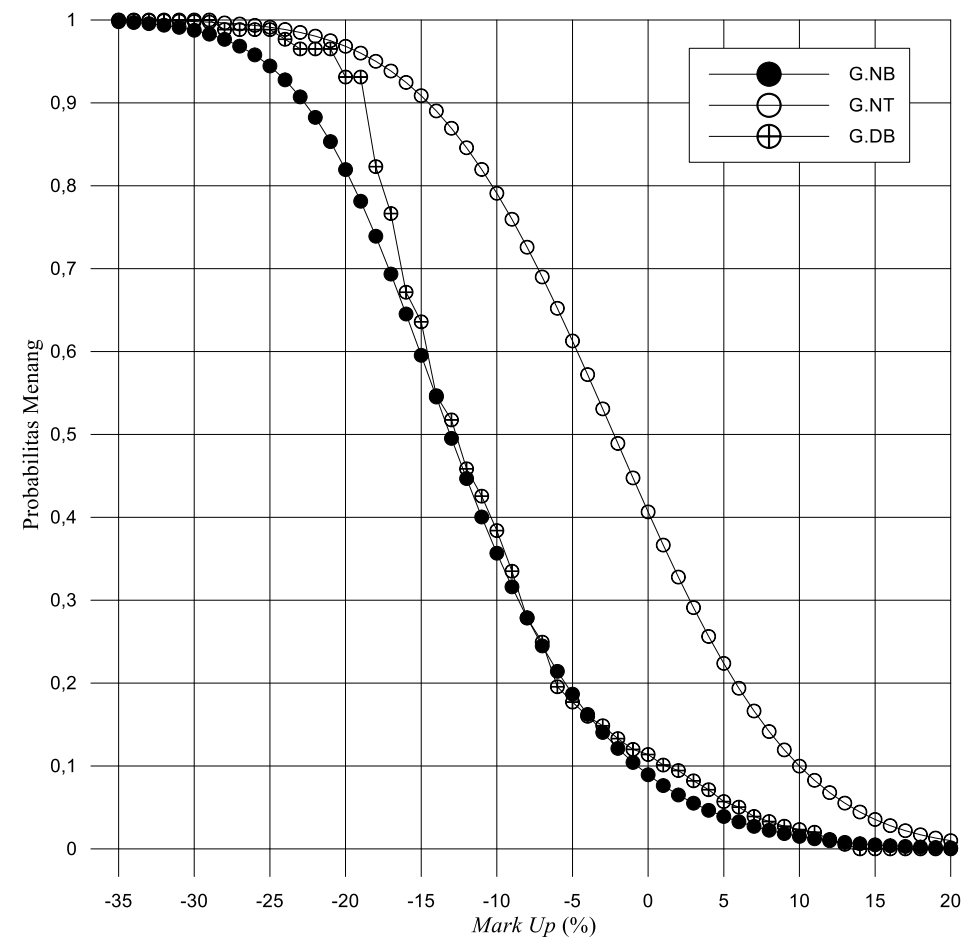

Gambar 1. Grafik Mark up vs. Probabilitas Menang Model Gates

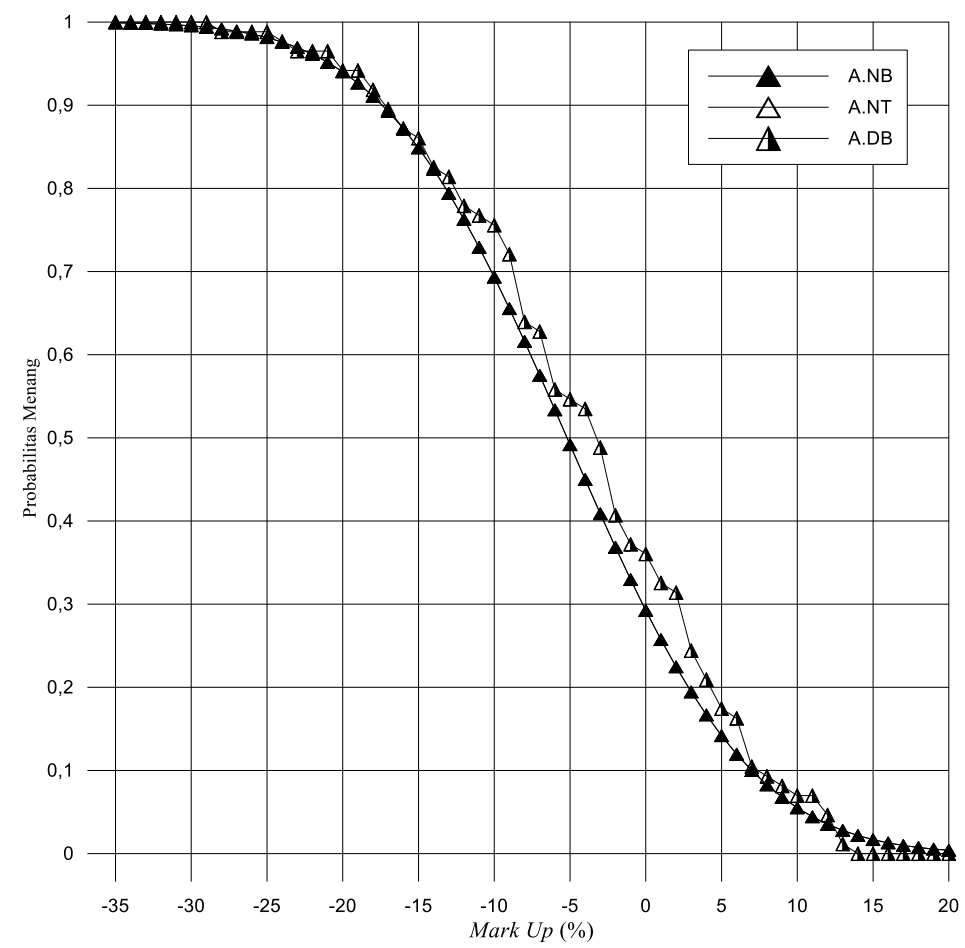

Gambar 2. Grafik Mark up vs. Probabilitas Menang Model Ackoff \& Sasieni 


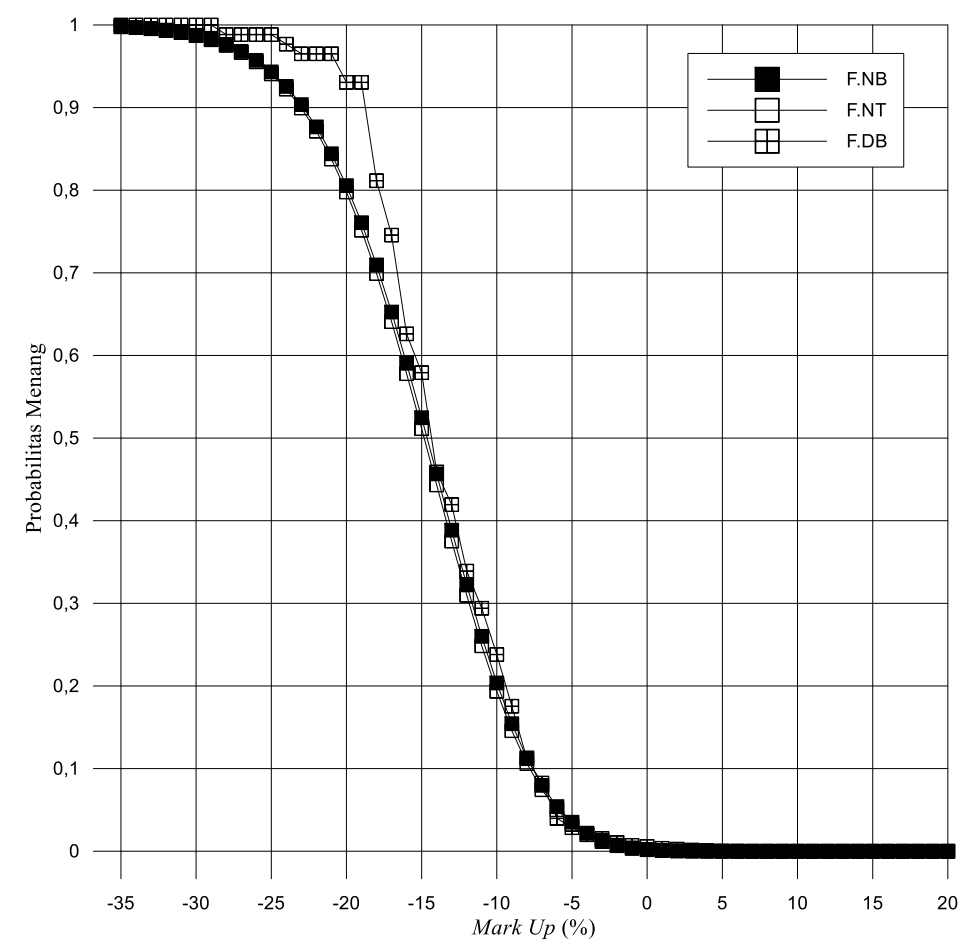

Gambar 3. Grafik Mark up vs. Probabilitas Menang Model Friedman

\section{Mark Up Optimum Model Gates, Ackoff \& Sasieni, dan Friedman}

Hasil perhitungan probabilitas menang semua model selanjutnya digunakan untuk menghitung expected profit dan mark up optimum. Grafik mark up vs. expected profit semua model ditunjukkan sebagai berikut.

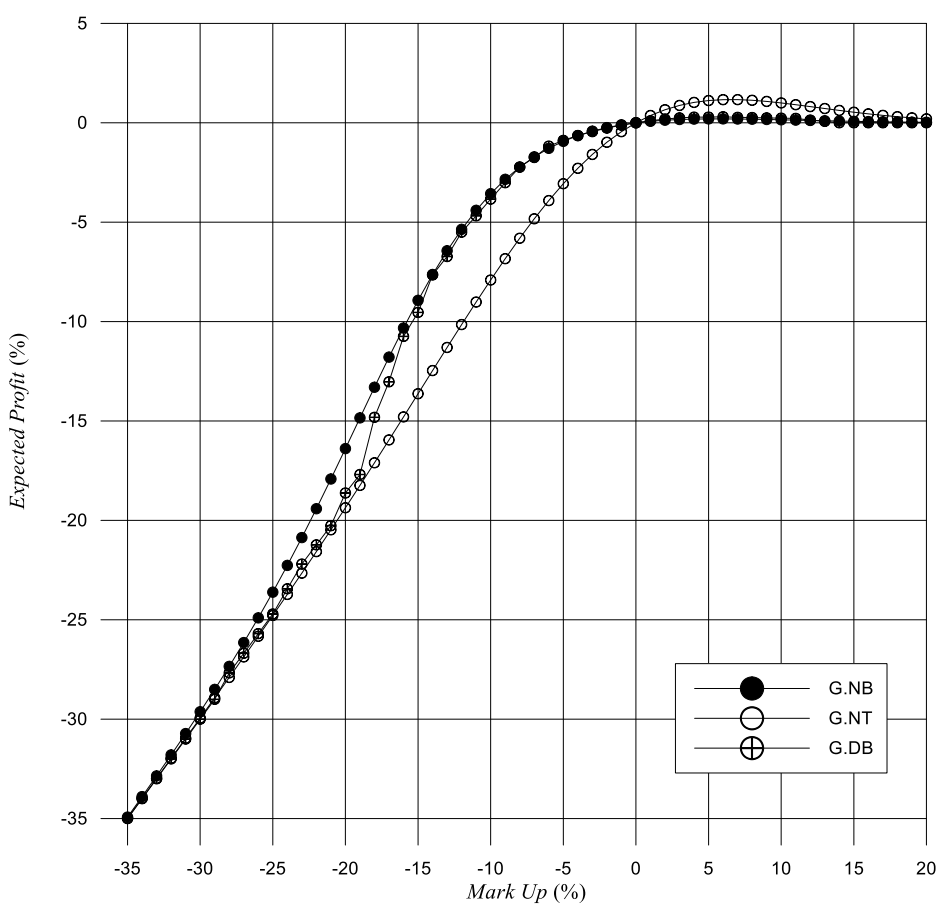

Gambar 4. Grafik Mark Up vs. Expected Profit Model Gates 


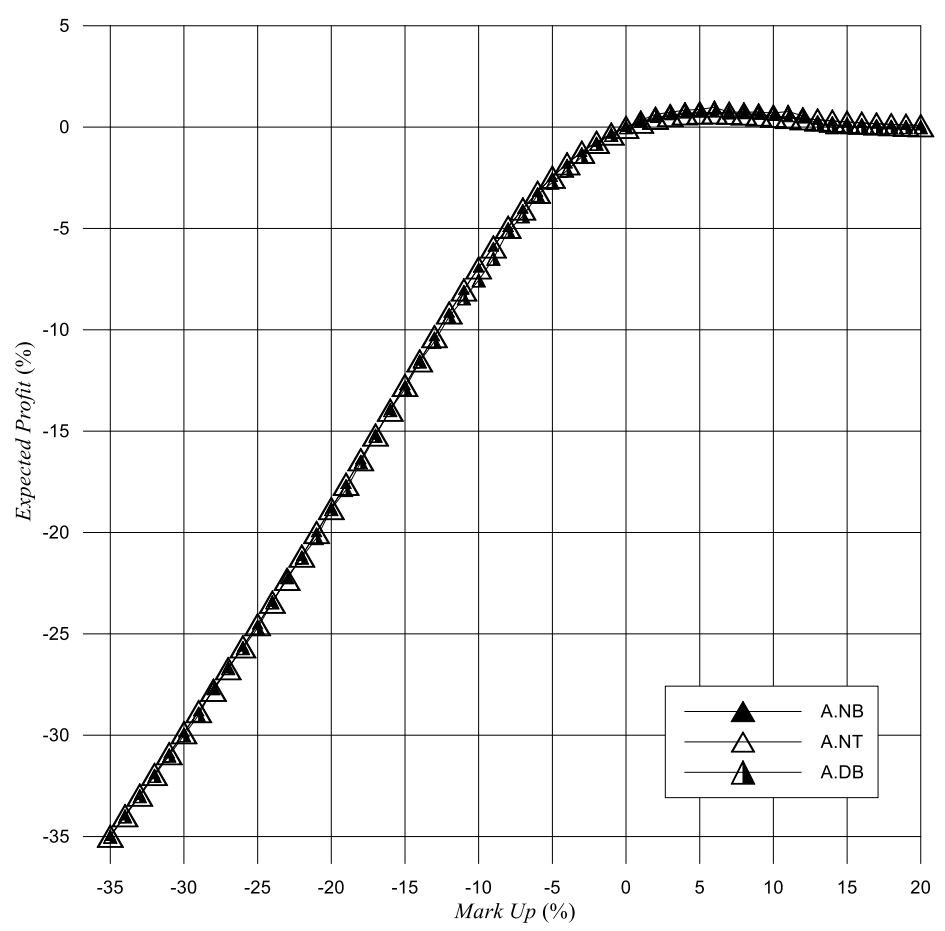

Gambar 5. Grafik Mark Up vs. Expected Profit Model Ackoff \& Sasieni

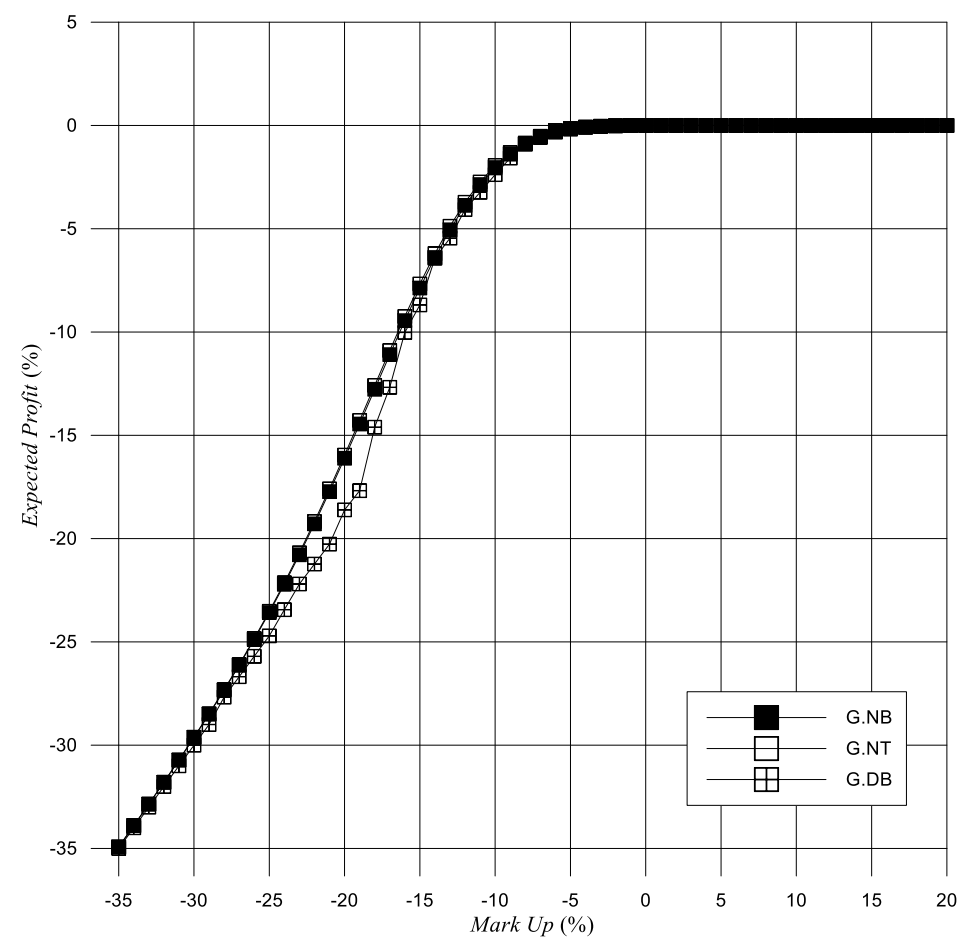

Gambar 6. Grafik Mark Up vs. Expected Profit Model Friedman

Mark up optimum adalah mark up dengan expected profit maksimum dari grafik-grafik diatas. Hasil nilai mark up optimum ditunjukkan pada tabel 6.

\section{Pengujian Model}

Probabilitas menang dari mark up optimum semua model kemudian dibandingkan dengan persentase menang dari 30 data yang telah disisihkan, kemudian dihitung selisihnya untuk mengetahui tingkat akurasi dari model-model yang diuji. 
Tabel 6. Hasil Pengujian

\begin{tabular}{|c|c|c|c|c|c|}
\hline Model & Jenis Distribusi & $\begin{array}{c}\text { Mark Up } \\
\text { Optimum (\%) }\end{array}$ & $\begin{array}{c}\text { Persentase } \\
\text { Analisis } \\
(\%) \\
\end{array}$ & $\begin{array}{l}\text { Persentase } \\
\text { Uji (\%) }\end{array}$ & $\begin{array}{c}\text { Selisih } \\
\text { Persentase } \\
(\%) \\
\end{array}$ \\
\hline \multirow{3}{*}{ Gates } & Normal Berganda (G.NB) & 6 & 3,27 & 27,00 & 23,73 \\
\hline & Normal Tunggal (G.NT) & 7 & 16,64 & 20,00 & 3,36 \\
\hline & Diskrit Berganda (G.DB) & 6 & 5,04 & 27,00 & 21,96 \\
\hline \multirow{3}{*}{$\begin{array}{l}\text { Ackoff \& } \\
\text { Sasieni }\end{array}$} & Normal Berganda (A.NB) & 6 & 11,96 & 20,00 & 8,04 \\
\hline & Normal Tunggal (A.NT) & 6 & 11,96 & 20,00 & 8,04 \\
\hline & Diskrit Berganda (A.DB) & 6 & 16,28 & 20,00 & 3,72 \\
\hline \multirow{3}{*}{ Friedman } & Normal Berganda (F.NB) & 3 & 0,02 & 30,00 & 29,98 \\
\hline & Normal Tunggal (F.NT) & 3 & 0,02 & 30,00 & 29,98 \\
\hline & Diskrit Berganda (F.DB) & 2 & 0,26 & 33,00 & 32,74 \\
\hline
\end{tabular}

Dari hasil perhitungan analisis mark up optimum yang ditunjukkan pada tabel 6 didapatkan hasil pembahasan sebagai berikut:

1) Model Friedman dengan ketiga jenis distribusi selalu menghasilkan nilai mark up optimum terendah, sedangkan model Gates dan Ackoff \& Sasieni menghasilkan nilai mark up optimum yang lebih besar.

2) Persentase menang hasil analisis model Friedman jauh lebih rendah dengan persentase menang hasil uji. Hal ini menunjukkan bahwa model Friedman merupakan metode yang 'pesimis' dalam memberikan nilai mark up optimum.

3) Model Friedman dengan distribusi normal berganda dan normal tunggal menghasilkan nilai mark up optimum yang sama besar yaitu 3\%. Sehingga apabila ingin mendapatkan nilai mark up optimum terendah yang mudah dan cepat, lebih baik menggunakan distribusi normal tunggal.

\section{KESIMPULAN}

Kesimpulan yang dapat ditarik dari penelitian ini adalah sebagai berikut:

1) Model Strategi Penawaran Gates, Ackoff \& Sasieni, dan Friedman dapat digunakan untuk mendapatkan grafik hubungan antara mark up vs. probabilitas menang yang dapat digunakan untuk menentukan harga penawaran.

2) Model Strategi Penawaran Gates, Ackoff \& Sasieni, dan Friedman menghasilkan nilai mark up optimum sebagai berikut:

a. Model Gates menghasilkan nilai mark up optimum menggunakan distribusi normal berganda, normal tunggal, dan diskrit berganda secara berurutan sebesar $6 \%, 7 \%$, dan $6 \%$.

b. Model Ackoff \& Sasieni menghasilkan nilai mark up optimum menggunakan distribusi normal berganda, normal tunggal, dan diskrit berganda secara berurutan sebesar $6 \%, 6 \%$, dan $6 \%$.

c. Model Friedman menghasilkan nilai mark up optimum menggunakan distribusi normal berganda, normal tunggal, dan diskrit berganda secara berurutan sebesar $3 \%$, 3\%, dan $2 \%$

3) Model Strategi Penawaran Friedman menghasilkan nilai mark up optimum terendah untuk setiap metode distribusi. Namun persentase menang hasil analisis Friedman jauh lebih 
rendah dari persentase menang hasil uji, ini menunjukkan bahwa model Friedman merupakan model yang 'pesimis' dalam memberikan nilai mark up.

4) Jika kontraktor ingin mendapatkan nilai mark up optimum dengan peluang menang yang paling besar maka gunakan Model Strategi Penawaran Friedman. Jika kontraktor ingin mendapatkan nilai mark up optimum yang lebih besar maka gunakan Model Strategi Penawaran Gates atau Ackoff \& Sasieni. Hal ini dapat dilakukan apabila permintaan pasar sedang tinggi.

\section{DAFTAR RUJUKAN}

[1] S. Nokes, The Definitive Guide to Project Management, London: FT Press, 2007.

[2] Project Management Institute, A Guide to the Project Management Body of Knowledge, Pennsylvania: Project Management Institute, Inc., 2010.

[3] Peraturan Pemerintah, "Penyelenggaraan Jasa Konstruksi," 30 Mei 2000. [Daring]. Tersedia pada: https://peraturan.bpk.go.id/Home/Details/53213/pp-no-29-tahun-2000.

[4] S. C. L. W. J.H. Rankin, "Contractor Selection: Qualification and Bid Evaluation," Canadian Journal of Civil Engineering, vol. 23, pp. 117-123, Februari 1996.

[5] Peraturan Presiden, "Peraturan Presiden Nomor 54 Tahun 2010," 6 Agustus 2010. [Daring]. Tersedia pada: https://jdih.lkpp.go.id/regulation/peraturan-presiden/peraturanpresiden-nomor-54-tahun-2010.

[6] Peraturan Presiden, "Peraturan Presiden Nomor 16 Tahun 2018," 22 Maret 2018. [Daring]. Tersedia pada: https://jdih.Ikpp.go.id/regulation/peraturan-presiden/peraturan-presidennomor-16-tahun-2018.

[7] R. H. K. S. T. C. Yuliana, "Bidding Strategy Using Friedman Model for Building Construction Project in Banjarbaru Indonesia," Journal of Civil, Construction and Environmental Engineering, vol. 1, no. 1, pp. 12-17, 2016.

[8] L. Friedman, "A Competitive-Bidding Strategy," Operations Research, vol. 4, pp. 104-112, 1956.

[9] H. Patmadjaja, "Model Strategi Penawaran untuk Proyek Konstruksi di Indonesia," Dimensi Teknik Sipi, vol. 1, pp. 1-7, 1999. 